\title{
CHAPTER 10 \\ ANALYSIS AND PLANNING \\ OF PRODUCTION EFFICIENCY \\ IN THE ECONOMIC SECURITY ENSURING SYSTEM
}

\section{Fisunenko P. A.}

\section{INTRODUCTION}

In the conditions of reforming the Ukraine economy, the introduction of market relations is important to constantly improve production management, which is highly dependent on the prediction of development prospects, on the forecast as a means of knowing the future. The state of affairs in the Ukraine economy remains extremely complex. It is forced to overcome the consequences of the planning and distribution system of the economy, its structural deformations, costly mechanism of pricing and non-competitive ability. So the ability to develop business plans becomes extremely relevant. Forecasting allows us to take alternative paths and to anticipate future development outcomes. Planning - is one of the well-known parts of entrepreneurial activity, which forms the basis for the efficient operation of the enterprise. Planning of enterprise activity must meet the requirements of market economies and response to all processes that occur in the country. Successful work of the enterprise depends on the availability of necessary resources and their efficient use. For effective promotion of work at the enterprise it is necessary to implement a management system of the production efficiency. The reliability of this system is the minimization of resources in each unit of output and will become the basis of the enterprise economic security system.

The issues of forecasting and planning in terms of market relations are constantly attracting the attention of scientists. And business planning is given considerable attention in educational publications and scientific publications on enterprise economics, strategic management, analysis of economic activity, as well as in regulatory documents of state authorities. Studies of such economists as: Alan West, R. Akkoff, and M.A. Belov, V.Yu. Brink, V.P. Burov, O.D. Vasilik, V.G. Vasilkov, N.P. Goncharova, B.E. Grabovetsky, M.P. Gruzinov, O.G. Dacia, L.M. Dragun, P. Drucker, O.S. Ivanilov, E.A. Zin, V.O. Korostelov, 
P. Kotler, V.G. Kotlyarova, E. Land Peter, V.E. Moskalyuk, V.M. Oparin, S.F. Pokropyvny, A.M. Poddyrogin, M. Porter, N.A. Savelyeva, V.A. Sidun, G.M. Tarasyuk, M.G. Tverdohlib, V.M. Tymoshenko, M.O. Turchenyuk, R.B. Tian, T.O. Primak, S.M. Pokropivny, Yu.V. Ponomaryova, D. Khan, G.O. Shvydanenko, T.I. Yatskiv and others. The works of these authors are devoted to the methods of planning and forecasting, technologies of development of plans and forecasts at the enterprise, analysis of efficiency of forecasting and planning of activity of the enterprise, analysis of consumer requirements and activity of competitors, etc. However, the issue of methodological support for prospective analysis (quantitative, qualitative and factor analysis), which should be carried out when developing a business plan, is not sufficiently covered. Also, despite the large number of publications, further research on the methodological support for planning the activity of the enterprise in the direction of increasing the efficiency of resource use is needed. Resource planning methodology should be based on the economic law of labour productivity growth and be an integral element (tool) of the production efficiency management system.

\subsection{Forecasting and planning}

Any management decision is inherently predictable. Forecasting provides a fundamental basis for entrepreneurial activity in any field. Forecasting the development of the enterprise involves determining the factors that affect the structure and volume of demand, the dynamics of its changes. Developing forecasts and drawing up plans on the basis of a market economy is a constant condition for the survival of any enterprise. In the conditions of the market, the pre-planned analysis of possible options for development, actions in the future, external and internal factors is of great importance. This is called forecasting. According to V.A. Sidun, forecasting is an element of in-house planning. Forecasting involves exploring the prospects of particular sectors of the national economy and entire regions. It is on this basis that the largest companies formulate the overall purpose of the development of the company as a whole and its individual divisions. As an element of inhouse forecasting planning, it is directly related to marketing and takes the form of a firm's market strategy ${ }^{1}$.

\footnotetext{
${ }^{1}$ Сидун В.А., Пономарева Ю.В. Экономика предприятия: учебное пособие. Харьков : ХДУХТ, 2006. $261 \mathrm{c}$.
} 
The importance of planning is expressed in the famous aphorism: «Plan or be planned». The point of the statement is that a firm that does not know or does not consider it necessary to plan its activities, itself is the object of planning, a means to achieve another's goal. Planning is a subjective activity of people, which, based on the study of patterns, any phenomena and processes (aspects of social life), determine their development (state of motion) in the near and distant periods of time. Planning at an enterprise is the planning of all its income and spending directions to ensure the development of the enterprise. Planning is done by drawing up financial plans of different content and purpose depending on the tasks and objects of planning. Unlike planning, forecasting is predominantly forward-looking and, being a component of planning, differs significantly from the latter. Forecasting is a system of quantitative and qualitative research aimed at identifying trends in the development of an object and finding the best ways to achieve its goals. A prediction is a probabilistic judgment about the state of any object or phenomenon in the future with a relatively high degree of certainty made by specialized scientific research. Forecasting is applied at the preliminary (pre-planned) stage of development and helps to develop the concept of economic development of an object or phenomenon for the planned period. It also plays a role at the stage of plan implementation, in evaluating the achieved results, finding opportunities and directions of additional management influences intended to eliminate deviations from the outlined plan of the development trajectory. ${ }^{2}$

According to O.S. Ivanilov, the forecast is a scientifically grounded hypothesis regarding the probable future state of the economic system and the economic objects and indicators that characterize this state. Development, compilation of forecasts is called forecasting ${ }^{3}$.

The forecast outlines the scope and opportunities within which realworld goals and objectives can be formulated, identifies problems that should be the object of development in the plan. Developing a forecast and forming an order portfolio in a market environment are interrelated stages within the overall planning within an enterprise-specific framework. The differences between them are that the formed order portfolio reflects and embodies the decision already made, and the forecast is the search for a potential, realistic, economically correct

\footnotetext{
${ }^{2}$ Швиданенко Г.О., Васильков В.Г., Гончарова Н.П. та ін. Економіка підприємства : підручник / Київ : КНЕУ, 2009. 598 с.

${ }^{3}$ Іванілов О.С. Економіка підприємства: підруч. Київ : Центр учбової літератури, 2009. 728 с.
} 
solution. The formed portfolio of orders at the enterprise is perceived as a result of all types and stages of work, it must be qualitatively homogeneous and aimed at achieving the chosen goal. The forecast opens the possibility of different development options, analyzes and substantiates them. The forecast can look at the various principles of economic policy and the combination of objective and subjective, economic and non-economic factors. It does not set out any specific objectives for the plan, but it does contain the material needed to develop them. Economic forecasts can be short-term (up to 3 years), medium-term (5-7 years), long-term (over 10 years). In this case, the organization of forecasting activities requires the provision of the necessary counter flows of information ${ }^{4}$.

The essence of planning lies in the development and justification of goals, identifying the best methods and ways to achieve them when effectively using all types of resources necessary to accomplish the tasks and establish their interaction. In the planning process, each business should answer the following questions: What should be done and why? When will it be done and Who will do it? Where will it be done and What is needed for it? Addressing these issues is a planning function that serves as a basis for decision-making and is a management activity that involves the development of goals and objectives of production management, as well as identifying ways to implement plans to achieve the goals. The process of planning the activity of enterprises includes many components: production and sale of products, its cost, security of labour, material and financial resources, financial results of work, financial condition of the enterprise, its investment activities. These are the objects of enterprise planning that are considered as a whole and through which its object is revealed. Since planning is the process of preparing decisions about goals, methods and methods of achieving them by purposeful comparative evaluation of different alternative actions under the envisaged conditions, and their adoption is always related to the use of resources, then the resources of the enterprise and are to a greater extent the subject of planning at the enterprise ${ }^{5}$.

The term «resource» - means a stock, a source. Resources include stocks and sources of raw materials, assets and cash, labour. Resources -

\footnotetext{
${ }^{4}$ Грабовецький Б.С. Планування та економічне прогнозування : навч. посіб. Вінниця : ВНТУ, 2013. $66 \mathrm{c}$.

${ }_{5}^{5}$ Тарасюк Г.М., Шваб Л.І. Планування діяльності підприємства : навч. посіб. Київ : «Каравела», 2005. $312 \mathrm{c}$.
} 
a set of tangible and intangible elements that directly or indirectly participate in the production process 5 .

In our opinion, when planning the activity of the enterprise, we must first consider the production resources, namely fixed assets, working capital and manpower. In this context, fixed assets should be understood as one-off capital costs associated with the production of products that retain their natural shape over a long period of time and transfer their value in parts to the value of the output. Working capital is also a one-time capital expenditure that is advised (or available) to create (hold) circulating production and rotation funds that ensure the continuity of production and sales. Labour resources, in a way, can also be considered as one-time capital expenditures that an enterprise incurs to support the production process. In addition to the current costs associated with the use of labour (wages and accruals), the company also makes capital, which is not included in the cost - this can be the cost of finding staff, training and skills, creating working conditions and living conditions, recreation and wellness, etc.

The logic of attributing fixed assets, working capital and manpower to the category of one-time capital expenditures is that they share a common nature, origin - these are funds, capital that an enterprise advances in its activities. The «disposability» and "capital» of these costs are that they are made at a single point in time in a large amount (purchase of equipment, buildings, structures, inventories, personnel), and they are reimbursed in parts (depreciation, write-off of part of inventories at cost) made in a certain period of production, etc. for a long time. Much of it remains on the balance sheet (capitalized) in the form of resources, undamaged costs, unused costs.

The basis of enterprise resource planning should be based on the law of productivity growth (efficiency) of labour formulated by K. Marx. «Increasing labour productivity is precisely that the proportion of living labour decreases, and the proportion of past labour (embodied in means of production) - increases, but increases so that the total amount of labour in each unit of product decreases» ${ }^{6}$. The need to minimize resources in each unit of product also derives from the laws of increasing needs and the relative scarcity of resources.

\footnotetext{
Довгаль Н.С. Ресурсний потенціал підприємства: теоретичні основи. Науково-технічна інформаиія. 2009. С. 42-45.

${ }^{6}$ Маркс К. Капитал / Маркс К., Энгельс Ф. // Сочинения. 2-е изд. Москва : Государственное издательство политической литературы, 1955-1981 гг. Т. 25. Ч. II. 286 с.
} 
It is important to note that the increase in labour productivity (production efficiency) indicates a faster growth in output compared to the increase in labour costs (living and past). This principle should also be used in planning the activities of an enterprise.

Thus, efficient use of resources is the most important factor in ensuring the solvency, creditworthiness and financial stability of the enterprise, maintaining its competitiveness, generating sufficient resources for development and obtaining sufficient profit. Resource efficiency depends on factors such as technical progress and implementation of its achievements in production, improvement of production organization, improvement of product quality, improvement of planning and increase of production automation, optimization of running costs.

To solve the problem of increasing production efficiency at enterprises, it is necessary to implement an appropriate system - the system of production efficiency management. The activities of this system should be aimed at the continuous minimization of resources and costs in each unit of output. In terms of a systematic approach, the proposed mechanism is a set of goals, criteria, methods and functions designed in accordance with economic laws as tools needed to achieve the goal. This mechanism is designed to minimize the costs of the enterprise and includes a set of measures (technical, technological, organizational, social, economic) aimed at minimizing resources (fixed assets, working capital, labour) and costs in each unit of output.

One of the tools of this production efficiency management system is analysis, the methodological support of which is primarily based on factor analysis. Factor analysis is a technique of complex systematic study and evaluation of the influence of factors on the value of productive indicators. The role of factor analysis in the management of economic systems is that it gives the opportunity to form and change the parameters of the studied object by appropriate selection and adjustment of the factors that caused them. Factor analysis is an integral part of the balance sheet method of planning, providing for the reconciliation of the entire amount of costs and each element with the sources of their financing. Factor analysis methodology is universal, it can be used for analysis of all spheres of activity of the enterprise, and above all, for planning.

In the real production, in real time, the outputs and resources of the enterprise change. These changes are accepted as factors of the first 
kind, which will be considered directly when conducting factor analysis. Second-class factors include the actions of those responsible for resource efficiency (who is to blame for reducing resource efficiency). Secondclass factors are identified on the basis of an analysis of the authority and responsibility of direct executors conducted by management.

The basis of factor analysis and evaluation of efficiency of use of enterprise resources and costs is based on the algorithm:

$$
\mathrm{Ep}=\mathrm{Ir}, \mathrm{c} / \mathrm{Io} \text {, }
$$

where Ir,c; Io - respectively, the index of resources and costs, the index of outputs of the enterprise. Many possible results of the calculation of the relation (1) were formalized and displayed in the form of a diagram (Figure 1). The vertical axis delayed the change in the outputs. And upward growth of the outputs was recorded (Io $>1$ ), while depositing Io -1 ; down from «1»-decrease in output, when Io $<1$, delayed $1-$ Iкр. On the horizontal axis delayed change of resources and costs of the enterprise. And to the right of «1» recorded the growth of resources and costs, that is, cases when Ir,c $>1$, delayed Ir,c -1 . To the left of «1»- reduced resources and costs (when Ir,c $<1$ ), delayed $1-$ Ir,c.

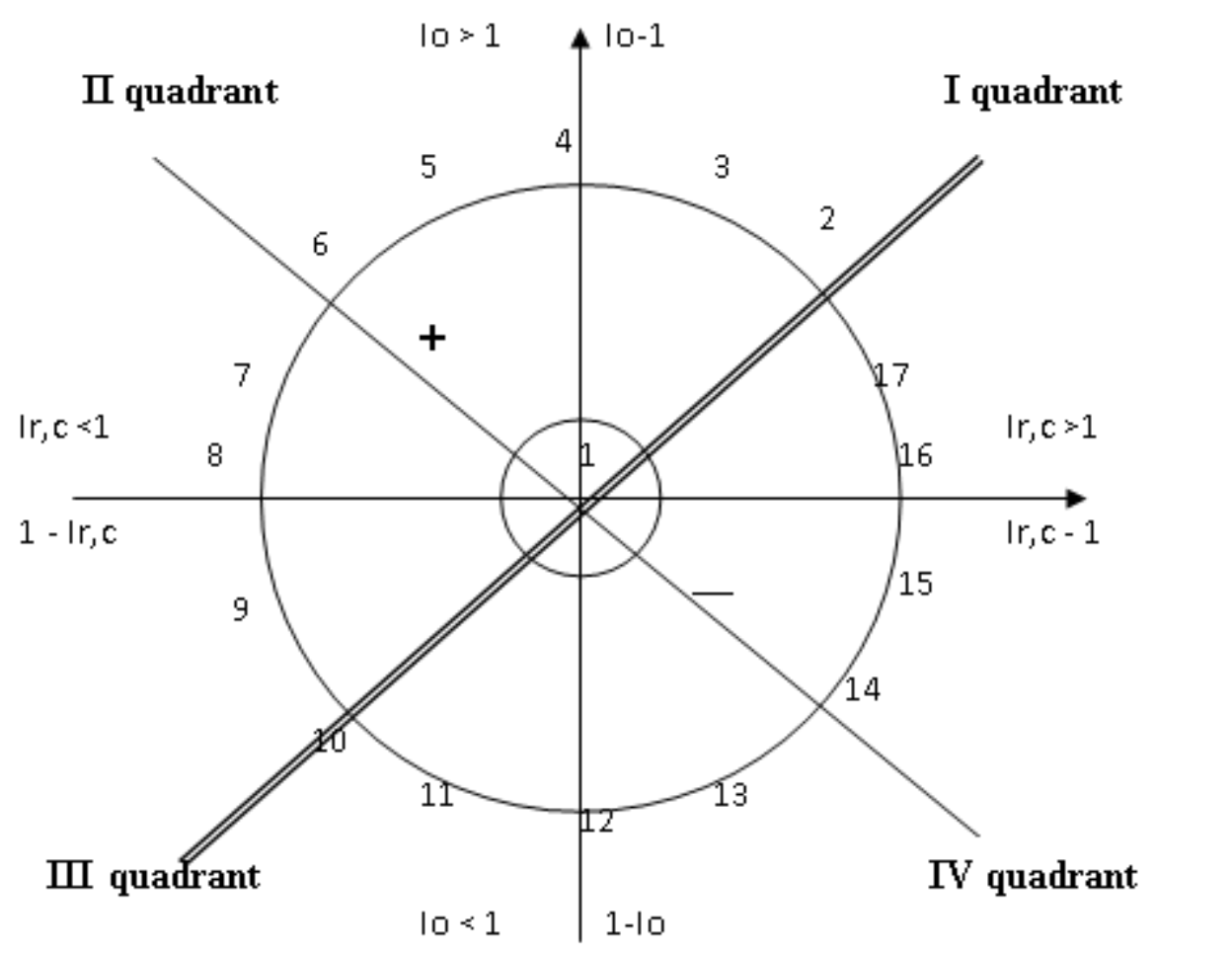

Figure 1. Resource Variables Ratio (Ir,c) and the outputs (Io) 
Thus, we obtained 17 types of sets of points of the results of the calculation of the relation (1) between Io and Ir,c. Of these, there were 7 types of ratios, in which the result of changes in the numerator and denominator in time in each unit of the outputs of the resources and costs became less (than in the basic variant). This is the set of points in sector 3, on lines $1-4$, in sector 5 , on lines 1-6, in sector 7, on lines $1-8$, in sector 9 .

Here, the correlation results inform the user about the increase in resource efficiency compared to with the basic period. In addition, there are 10 types of results of the calculation of the relation (1) between the variable of output and the variable resources and costs, in which in each unit of outputs the resources and costs were kept at the same level or increased compared to the base variant. This is at point «1», many points on line $1-10$, in sector 11 , on line $1-12$, in sector 13 , on line $1-14$, in sector 15 , on line $1-16$, in sector 17 , on lines $1-2$. Here, the results of the relationship inform about the decrease in the efficiency of use of resources and costs of the enterprise, compared with the basic period. In this case, the controlling must to identify centres of responsibility (persons, group of persons) for wrongly made in the past technical, technological, organizational, economic, social decisions that develop recommendations for eliminating factors that adversely affect the economy of the enterprise and the use of resources. Each type of relationship has its own evaluation algorithm, what are given in Table 1.

Planning as part of a resource efficiency management system must meet the following requirements:

- planning as a management method should «work» in the enterprise resource efficiency management system;

- planning of resources should be done «for themselves»;

- the rate and limit (limits) of resources and costs should be achievable, but as norms and limits are mastered, they must be revised in the direction of strengthening;

- the methodology for calculating the rates and limits for resources and costs should be simple and free of subjective elements.

Factor analysis methodology provides the user with boundary conditions for the relationship between variable end results and variable resources. In addition, this technique gives a range of ways to increase the efficiency of use of enterprise resources, namely: from Fig. 1 shows that line 10-1-2 represents a set of threshold values of the planned values of the resources required for production of products, the observance of which will necessarily contribute to the increase of resource efficiency (Figure 2). 
Table 1

Factor estimation algorithm evaluation of enterprise efficiency

\begin{tabular}{|c|c|c|c|c|c|}
\hline \multirow{2}{*}{ Types } & \multicolumn{2}{|c|}{ Conditions } & \multirow{2}{*}{ Evaluation algorithm } & \multirow{2}{*}{$\begin{array}{l}\text { Point }(\mathrm{T}) \\
\text { line }(\mathrm{L}) \\
\text { sector }(\mathrm{S})\end{array}$} & \multirow{2}{*}{$\begin{array}{c}\text { Rating }\langle(+)- \\
\text { is effective, } \\
\text { «-»- } \\
\text { is ineffective }\end{array}$} \\
\hline & $\begin{array}{c}\text { the outputs } \\
\text { (O) }\end{array}$ & $\begin{array}{c}\text { resources } \\
\text { and costs } \\
(\mathrm{R}, \mathrm{C})\end{array}$ & & & \\
\hline 1. & $\mathrm{Io}=1$ & $\mathrm{Ir}, \mathrm{c}=1$ & $\{\mathrm{Io}-1 ; 1-\mathrm{Io}\}=\{\mathrm{Ir}, \mathrm{c}-1 ; 1-\mathrm{Ir}, \mathrm{c}\}$ & T.1 & - \\
\hline 2. & Io $>1$ & $\mathrm{Ir}, \mathrm{c}>1$ & Io-1=Ir,c-1 & L. $1-2$ & - \\
\hline 3. & Io $>1$ & $\mathrm{Ir}, \mathrm{c}>1$ & Io-1>Ir,c-1 & S.3 & + \\
\hline 4. & Io $>1$ & $\mathrm{Ir}, \mathrm{c}=1$ & Io-1>\{Ir,c-1;1-Ir,c $\}$ & L. $1-4$ & + \\
\hline 5. & Io $>1$ & $\mathrm{Ir}, \mathrm{c}<1$ & Io-1>1-Ir,c & S. 5 & + \\
\hline 6. & Io $>1$ & Ir,c $<1$ & Io-1=1-Ir,c & L. $1-6$ & + \\
\hline 7. & Io $>1$ & $\operatorname{Ir}, \mathrm{c}<1$ & Io-1<1-Ir,c & S. 7 & + \\
\hline 8. & $\mathrm{Io}=1$ & $\operatorname{Ir}, \mathrm{c}<1$ & $\{$ Io-1;1-Io $\}<1-$ Ir,c & L. $1-8$ & + \\
\hline 9. & Io $<1$ & $\operatorname{Ir}, \mathrm{c}<1$ & $1-\operatorname{Io}<1-\operatorname{Ir}, \mathrm{c}$ & S. 9 & + \\
\hline 10. & Io $<1$ & $\mathrm{Ir}, \mathrm{c}<1$ & $1-\mathrm{Io}=1-\mathrm{Ir}, \mathrm{c}$ & L. $1-10$ & - \\
\hline 11. & Io $<1$ & $\operatorname{Ir}, \mathrm{c}<1$ & $1-\operatorname{Io}>1-\operatorname{Ir}, \mathrm{c}$ & S. 11 & - \\
\hline 12. & $\mathrm{I} 0<1$ & $\operatorname{Ir}, \mathrm{c}=1$ & $1-\mathrm{Io}=\{\operatorname{Ir}, \mathrm{c}-1 ; 1-\mathrm{Ir}, \mathrm{c}\}$ & L. $1-12$ & - \\
\hline 13. & Io $<1$ & Ir,c $>1$ & 1-Io $>$ Ir,c-1 & S. 13 & - \\
\hline 14. & $\mathrm{Io}<1$ & $\operatorname{Ir}, \mathrm{c}>1$ & $1-\mathrm{Io}=\mathrm{Ir}, \mathrm{c}-1$ & L. 1-14 & - \\
\hline 15. & $\mathrm{I} 0<1$ & $\mathrm{Ir}, \mathrm{c}>1$ & $1-\mathrm{Io}<\mathrm{Ir}, \mathrm{c}-1$ & S. 15 & - \\
\hline 16. & $\mathrm{Io}=1$ & $\operatorname{Ir}, \mathrm{c}>1$ & $\{$ Io-1;1-Io $\}<$ Ir,c-1 & L. $1-16$ & - \\
\hline 17. & Io $>1$ & $\mathrm{Ir}, \mathrm{c}>1$ & Io- $1<$ Ir,c-1 & S. 17 & - \\
\hline
\end{tabular}

Required for the above calculations are the conditions under which:

$$
\begin{gathered}
\mathrm{I}_{\mathrm{o}}>\mathrm{I}_{\mathrm{r}, \mathrm{c}}, \\
\text { that is: } \frac{\mathrm{O}_{\mathrm{pl}}}{\mathrm{O}_{\mathrm{t}}}>\frac{\mathrm{R}, \mathrm{C}_{\mathrm{pl}}}{\mathrm{R}, \mathrm{C}_{\mathrm{t}}}, \\
\text { hence: } \mathrm{O}_{\mathrm{pl}} \times \mathrm{R}, \mathrm{C}_{\mathrm{t}}>\mathrm{O}_{\mathrm{t}} \times \mathrm{R}, \mathrm{C}_{\mathrm{pl}},
\end{gathered}
$$

The planned size of resources (absolute value) is determined by:

$$
\mathrm{R}, \mathrm{C}_{\mathrm{pl}}<\frac{\mathrm{O}_{\mathrm{pl}} \times \mathrm{RC}_{\mathrm{t}}}{\mathrm{O}_{\mathrm{t}}}
$$




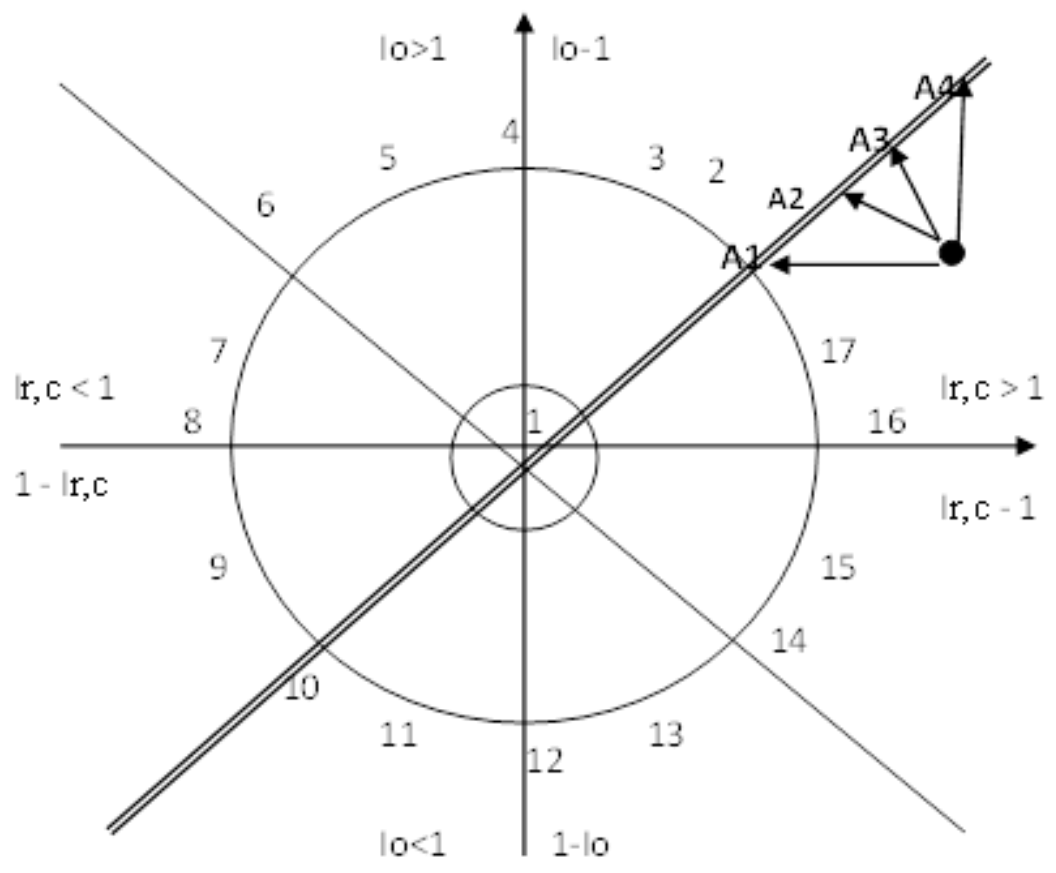

Figure 2. Information on directions of achievement of effective use of resources and costs of the enterprise

The proposed methodology for planning allows the development of several variants of plans (variability of planning). The planned size of resources depends on the planned production volume, which can be set in several variants (depending on the market situation). A prerequisite for achieving resource efficiency is the following inequality:

$$
\mathrm{PE}_{\mathrm{pl}}<\mathrm{PE}_{\mathrm{t}} \text {, }
$$

where PE - resources and costs per unit of outcomes of the enterprise (plan and fact).

That is, the resource intensity of the deliverables in the planning period should necessarily be below the same indicator in the reporting period.

To create several variants of plans, it is advisable to make a matrix (Table 2).

where $\mathrm{O}_{0}$ is the outcomes of the base (reporting) period;

$\mathrm{O}_{1}, \mathrm{O}_{2}, \ldots, \mathrm{O}_{\mathrm{j}}-$ planned value of outcomes (information of marketing service);

$\mathrm{R}, \mathrm{C}_{0}$ - value of resources and costs of the base (reporting) period;

$R, C_{1}, R, C_{2}, \ldots, R, C_{i}-$ estimated values of resources and costs of the planning period (variants of calculations $1,2, . ., \mathrm{i}$ ). 
The matrix of determining the effective size of resources and costs of the enterprise

\begin{tabular}{|c|c|c|c|c|c|}
\hline $\begin{array}{l}\text { Resources } \\
\text { and costs }\end{array}$ & $\mathrm{R}, \mathrm{C}_{0}$ & $\begin{array}{c}\mathrm{R}, \mathrm{C}_{1} \\
\mathrm{R}, \mathrm{C}_{1}<\frac{\mathrm{O}_{\mathrm{j}} \times \mathrm{RC}_{0}}{\mathrm{O}_{0}}\end{array}$ & $\begin{array}{c}\mathrm{R}, \mathrm{C}_{2} \\
\mathrm{R}, \mathrm{C}_{2}<\frac{\mathrm{O}_{\mathrm{j}} \times \mathrm{RC}_{0}}{\mathrm{O}_{0}}\end{array}$ & ..... & $\begin{array}{c}\mathrm{R}, \mathrm{C}_{\mathrm{i}} \\
\mathrm{R}, \mathrm{C}_{\mathrm{i}}<\frac{\mathrm{O}_{\mathrm{j}} \times \mathrm{RC}_{0}}{\mathrm{O}_{0}}\end{array}$ \\
\hline $\mathrm{O}_{0}$ & $\mathrm{PE}_{00}$ & $\mathrm{PE}_{10}$ & $\mathrm{PE}_{20}$ & $\ldots \ldots$ & $P E_{i 0}$ \\
\hline $\mathrm{O}_{1}$ & $\mathrm{PE}_{01}$ & $\mathrm{PE}_{11}$ & $\mathrm{PE}_{21}$ & $\ldots$ & $\mathrm{PE}_{\mathrm{i} 1}$ \\
\hline $\mathrm{O}_{2}$ & $\mathrm{PE}_{02}$ & $\mathrm{PE}_{12}$ & $\mathrm{PE}_{22}$ & $\ldots$. & $\mathrm{PE}_{\mathrm{i} 2}$ \\
\hline ..... & $\ldots$ & ..... & $\ldots \ldots$ & $\ldots$. & $\ldots \ldots$ \\
\hline $\mathrm{O}_{\mathrm{j}}$ & $\mathrm{PE}_{0 \mathrm{j}}$ & $P E_{1 j}$ & $P E_{2 j}$ & $\ldots .$. & $\mathrm{PE}_{\mathrm{ij}}$ \\
\hline
\end{tabular}

\subsection{Perspective analysis}

Analysis and planning are one of the important management functions without which no management decisions can be made by business entities. They are equivalent to management functions such as accounting, control, organization, communication and motivation.

Business planning with a business plan describes all the basic aspects of the enterprise, and the analysis examines the problems that it may face in the practice of its activities and identifies ways to solve these problems.

The business plan is the basis of enterprise management, at the same time search, research and project work, which provides the solution of the tasks that are facing the enterprise, regardless of its functional orientation. The business plan development process includes a detailed analysis of economic and organizational issues. A business plan is a document that contains a system of time and space-related activities and actions that are coordinated with the purpose and resources aimed at maximizing profit at minimum risks due to the implementation of an entrepreneurial project (agreement). The business plan considers the scientific, technical, technological, organizational, social and other aspects of the implementation of the entrepreneurial project, but focuses on its financial and economic aspects ${ }^{7}$.

In our opinion, according to the business plan, a prospective analysis and evaluation of the efficiency of using the resources of the

\footnotetext{
${ }^{7}$ Волкова Н.А., Волчек Р.М., Гайдаєнко О.М. та ін. Економічний аналіз : навч. посіб. За ред. Волкової Н.А. Одеса : ОНЕУ, Ротапринт, 2015. 310 с.
} 
enterprise should be conducted. Such approach will allow to provide continuous increase of efficiency of activity of the enterprise.

The analysis should help management to answer the questions: how (effectively or ineffectively), how much (effectively or ineffectively) that influenced (factors), and what measures should be taken to improve resource efficiency, costs, production efficiency as a whole. Prospective analysis requires the development of methods for analytical support of production efficiency management system, including qualitative, quantitative and factor analysis.

Analysis is a logical method of scientific research, the essence of which is the imaginary or practical dismemberment of the whole into its constituent parts and their study in all the variety of essential relationships. Prospective analysis is an analysis of future results of financial and economic activity of the enterprise. The most important tasks of prospective analysis are the preparation of the necessary analytical information to substantiate the prospective and current plans for the development of the enterprise, assessment of the reality of the implementation of the planned plans ${ }^{8}$.

Prospective qualitative analysis of efficiency of use of resources and expenses of the enterprise helps to answer the question: «how?» the resources and costs of the enterprise were used effectively (or inefficiently). To carry out perspective qualitative analysis of resource efficiency, costs, efficiency of enterprise development as a whole, it is proposed to use the absolute values of fixed assets, working capital, labour resources, cost, production costs, commodity (gross) products. The algorithm of perspective qualitative analysis and estimation of the use of resources, costs of the enterprise $(\mathrm{E})$ is offered in the following form:

$$
\mathrm{E}_{1}=\frac{\sum_{\mathrm{t}=1}^{\mathrm{T}} \mathrm{I}_{\mathrm{r}, \mathrm{c}}}{\sum_{\mathrm{t}=1}^{\mathrm{T}} \mathrm{I}_{\mathrm{o}}}
$$

where $\sum_{t=1}^{T} I_{r, c}, \sum_{t=1}^{T} I_{o}-$ respectively, the sum of indices of resources, costs, the sum of indices of outcomes of the enterprise. When $\mathrm{E}_{1} \geq 1$, the conclusion is made about inefficient use of resources, costs of the enterprise, only if $E_{1}<1$ concludes about the effective use of resources,

\footnotetext{
${ }^{8}$ Тарасенко Н. В. Економічний аналіз : навч. посібник. 3-е видання. Львів : Новий світ, 2004. 344 с.
} 
costs of the enterprise, since in the planning period in each unit of outcomes the amount of resources and costs (required for production of outcomes), will decrease.

To perform a prospective qualitative analysis of resource efficiency, costs, production efficiency of the enterprise, you can also use relative indicators: capital consumption of products by fixed assets (FA) and working capital (WC), labour complexity (LCP), production cost (PC).

An algorithm for perspective qualitative analysis of resource efficiency, enterprise costs, which is carried out using capacity indicators is proposed in the form of the relation:

$$
E_{2}=\frac{\sum_{\mathrm{t}=1}^{\mathrm{T}} \mathrm{I}_{\mathrm{PE}}}{\mathrm{T}}
$$

where $\mathrm{I}_{\mathrm{PE}}-$ the index of resources and costs per unit of outcomes of the enterprise ( $\left.\mathrm{I}_{\mathrm{FA}}, \mathrm{I}_{\mathrm{WC}}, \mathrm{I}_{\mathrm{LCP}}, \mathrm{I}_{\mathrm{PC}}\right)$.

In the case of $\mathrm{E}_{\mathrm{PE}} \geq 1$ concludes that the resources and costs of the enterprise were used inefficiently during the analyzed period of time. Only when the $\mathrm{E}_{\mathrm{PE}}<1$, concludes that the resource efficiency, costs in the planning period compared with the baseline will increase.

Quantitative prospective analysis in the production efficiency management system answers the question «how much effectively (or ineffectively)» the resources and costs of the enterprise were used during the analyzed period.

For quantitative perspective analysis of resource efficiency and costs, enterprise efficiency, the following algorithm is proposed:

$$
\mathrm{E}_{3}=\sum_{\mathrm{t}=1}^{\mathrm{T}}\left(\mathrm{PE}_{\mathrm{t}}-\mathrm{PE}_{\mathrm{pl}}\right) \times \mathrm{O}_{\mathrm{pl}} \times \mathrm{K}
$$

where $\mathrm{PE}_{\mathrm{t}} ; \mathrm{PE}_{\mathrm{pl}}$ - resources and costs $(\mathrm{FA}, \mathrm{WC}, \mathrm{LCP}, \mathrm{PC})$ per unit of outcomes of the enterprise, respectively, in the base and planning periods; $\mathrm{K}$ - coefficient of efficiency of use of resources and costs of the enterprise.

The equation can have a positive, negative and zero solution. If $\mathrm{E}_{3} \leq 0$, the conclusion is made about inefficient use of resources and costs of the enterprise (negative value - reduction of profit due to increase of resource-, cost of production in the planned period in comparison with the base value). Only in the case of a positive value does it conclude that the increase in the efficiency of resource use and costs of the enterprise (a positive value - an increase in profit by 
reducing the indicator of resource-, cost-intensive products in the planned period compared with the base value).

The use of the proposed approaches to analysis and planning will ensure economic security.

\section{CONCLUSIONS}

The article defines the essence and tasks of analysis and planning of the efficient of the enterprise as a basis of the enterprise economic security system, the main purpose of which is to create the potential for survival of the enterprise in the conditions of dynamic change of the external environment, which creates uncertainty of the prospect. Effective functioning of the enterprise in modern conditions is impossible without use in management of methods of analysis and planning. The subject of enterprise analysis and planning is resources and costs. Efficient use of resources and costs is one of the important factors for improving production efficiency and ensuring economic security of the enterprise.

Well-known management scientist P. Drucker emphasized that efficiency is a consequence of the fact that «right and right things are done. And efficiency is a consequence of the fact that these things are created correctly» ${ }^{9}$. For the successful operation of the enterprise, ensuring and efficient use of resources and their minimization, it is necessary to implement a system of production efficiency management. The tool of this system is prospective analysis, the methodological support of which is based on qualitative, quantitative and factor analysis. The purpose of this system is to minimize resources per unit of outcomes of production.

A prospective qualitative analysis of the effective use of resources and costs of the enterprise determines how to use (effectively or ineffectively) the resources and costs of the enterprise. A prospective quantitative analysis determines how effectively (or ineffectively) the resources and costs of an enterprise are used. A prospective factor analysis identifies the factors that influenced resource and cost efficiency. Such approaches will allow to provide continuous increase of efficiency of activity of the enterprise.

The results of factor analysis make it possible to calculate the planned size of resources and costs, to comply with the requirements of

\footnotetext{
9 Питер Ф. Друккерр. Энциклопедия менеджмента: Пер. с англ. Москва : Издательский дом «Вильямс», 2004. 432 с.
} 
the law of increasing productivity (efficiency) of labour. An appropriate methodological approach is proposed for such calculations. In turn, factor analysis is an integral part of the balance sheet method of planning, whose methodology is versatile, it provides many ways to improve the efficiency of use of enterprise resources and allows you to develop several plans. In order to achieve efficient use of resources, the resource intensity of the deliverables in the planning period must necessarily be lower than in the reporting period.

\section{SUMMARY}

The results of theoretical content research, forecasting features and activities of the company analysis and planning and their interconnection are presented in this article. Directions of achievement on effective resources use are defined. The article describes the results of a study of approaches to analysis and planning of enterprise activity, their interaction. Methodical approach to planning of resources of company in production efficiency management system are suggested. The methodology of qualitative, quantitative and factor analysis are presented. The essence of business planning, perspective analysis, estimates of resource efficiency, costs of businesses and methodological approach, the algorithm and the method of calculation, which have been revealed and offered in this article. The use of the proposed approaches to analysis and planning will ensure economic security.

\section{REFERENCES:}

1. Бєлов М.А., Євдокимова Н.М. та ін. Планування діяльності підприємства : навч. посіб. Київ : КНЕУ, 2002. 45 с.

2. Васильків Т.Г., Качмарик Я.Д., Блонська В.І., Лупан Р.Л. Бізнес-планування : навч. посіб. Київ : Знання, 2013. 173 с.

3. Гетало В.П., Гончаров Г.О., Колісник А.В. Бізнес-планування : навч. посіб. Київ : Професіонал, 2008. 240 с.

4. Грабовецький Б.С. Планування та економічне прогнозування : навч. посіб. Вінниця : ВНТУ, 2013. 66 с.

5. Довгаль Н.С. Ресурсний потенціал підприємства: теоретичні основи. Науково-технічна інформаџія. 2009. С. 42-45.

6. Драгун Л.М., Левченко В.Ф., Бондаренко О.Л. Удосконалення аналізу ефективності використання обігових коштів підприємства. Фінанси України. 1998. № 12. С. 12-21. 
7. Швиданенко Г.О., Васильков В.Г., Гончарова Н.П. та ін. Економіка підприємства : підруч. Київ : КНЕУ, 2009. 598 с.

8. Волкова Н.А., Волчек Р.М., Гайдаєнко О.М. та ін. Економічний аналіз : навч. посіб. Одеса : ОНЕУ, Ротапринт, 2015. 310 с.

9. Сщенко П.С., Палкін Ю.І. Сучасна економіка : навч. посіб. Київ : Вища школа, 2005. 327 с.

10. Іванілов О.С. Економіка підприємства : підруч. Київ : Центр учбової літератури, 2009. 728 с.

11. Кушнір Т.Б., Немцов О.В. Теоретико-методичні аспекти формування системи планування на підприємстві. Вісник економічної науки України Вип. 1. Донецьк, 2009. С. 111-115.

12. Маркс К., Энгельс Ф. Капитал. 2-е изд. Москва : Государственное издательство политической литературы, 1955-1981 гг. T. 25. Ч. II. 286 c.

13. Москалюк В.С. Планування діяльності підприємства : навч. посіб. Київ : КНЕУ, 2005. 384 с.

14. Опарін В.М. Фінанси (загальна теорія) : навч. посібник. 2-е вид., доп. і перероб. Київ : КНЕУ, 2002. 240 с.

15. Питер Ф. Друкер. Энциклопедия менеджмента: Пер. с англ. Москва : Издательский дом «Вильямс», 2004. 432 с.

16. Покропивний С. М. Економіка підприємства : підруч. Київ : КНЕУ, 2001. 528 c.

17. Рязанцева В.В. Аналіз формування та використання прибутку підприємства. Статистика України. 2007. С. 40-43.

18. Сидун В.А., Пономарева Ю.В. Экономика предприятия : учебное пособие. Харьков : ХДУХТ, 2006. 261 с.

19. Смаковська Ю. Критерії експертної оцінки бізнесплану підприємницького проекту. Формування ринкової економіки в Україні. 2009. № 19. С. 434-438.

20. Тарасюк Г.М., Шваб Л.І. Планування діяльності підприємства : навч. посіб. Київ : «Каравела», 2005. 312 с.

21. Тарасенко Н.В. Економічний аналіз : навч. посібник. 3-е видання. Львів : Новий світ, 2004. 344 с.

\section{Information about the author:}

Fisunenko P. A.

Ph.D in Economics, Associate Professor, Department of Economics and Entrepreneurship, Prydniprovs'ka State Academy of Civil Engineering and Architecture, Ukraine 